\title{
History of Anesthesia
}

Gillian R. Hamilton BA, Thomas F. Baskett MB FRCSC

\section{In the arms of Morpheus: the development of mor- phine for postoperative pain relief}

Purpose: To analyse the historical development of morphine for postoperative analgesia and how this development was shaped by the evolution of anesthetic techniques.

Methods: After a systematic review of the literature, information was gathered from primary sources.

Principal Findings: In ancient medicine, some plant derivatives were used to alleviate pain including: alcohol, cannabis, mandrake, and opium. Over the past two centuries, opium and its derivatives have become the most widely used analgesics for severe pain. Before the development of general anesthesia, surgery was only performed out of extreme necessity. It is probable that an analgesic such as opium would have been given following surgery although its use may not have been recorded. The first description of postoperative opium was by James Moore in 1784. Morphine was isolated from opium by Friedrich Serturner in 1805. However, it was not until the development of the hypodermic needle and syringe nearly $50 \mathrm{yr}$ later that the use of morphine became widespread. Over the last century, various delivery systems for morphine have been developed including subarachanoid and epidural injection, and more recently patient-controlled intravenous, epidural and intranasal analgesia. In addition, many new opioids have been synthesized.

Conclusion: Since its isolation from opium almost $200 \mathrm{yr}$ ago, morphine remains the most widely used analgesic and the standard against which all new opioids for postoperative pain relief are compared.

Objectif : Décrire le développement historique de la morphine comme analgésique postopératoire et montrer comment il a été façonné par l'évolution des techniques anesthésiques.

Méthode : On a d'abord passé systématiquement en revue la documentation pertinente, puis rassemblé les informations des principales sources.

Constatations principales : La médecine ancienne utilisait certains dérivés de plantes pour soulager la douleur: l'alcool, le cannabis, la mandragore et l'opium. Au cours des deux derniers siècles, l'opium et ses dérivés sont devenus les analgésiques les plus utilisés contre la douleur vive. Avant l'avènement de l'anesthésie générale, l'intervention chirurgicale n'était réalisée qu'en cas d'extrême nécessité. II est probable qu'un analgésique comme l'opium ait été administré à la suite d'une opération sans qu'on en consigne l'emploi. La première description de l'utilisation postopératoire d'opium revient à James Moore en 1784. La morphine a été isolée de l'opium par Friedrich Serturner en 1805. Cependant, son usage ne s'est répandu qu'avec l'arrivée, 50 ans plus tard, de l'aiguille hypodermique et de la seringue. Pendant le siècle dernier, on a mis au point différents systèmes d'administration de la morphine, y compris l'injection sous-arachnoïdienne et péridurale et, plus récemment, l'analgésie intraveineuse, péridurale et intranasale contrôlée par le patient. De plus, nombre de nouveaux opioïdes ont été synthétisés.

Conclusion : Depuis que la morphine a été isolée de l'opium, il y a près de 200 ans, elle demeure l'analgésique le plus utilisé et une norme de comparaison pour tout nouvel opioïde utilisé pour soulager la douleur postopératoire.

From the Department of Obstetrics and Gynaecology, Dalhousie University, 5980 University Avenue, Halifax, Nova Scotia B3J 3G9 Canada.

Address correspondence to: T.F. Baskett MB FRCSC. Phone: 902-420-6788; Fax: 902-428-8640

Accepted for publication December 12, 1999. 
$\mathrm{P}$ AIN is an integral part of life and, as such, attempts to relieve pain must be as old as human-kind. Some of the earliest pharmacological methods of pain relief included the plant derivatives: alcohol, cannabis, mandrake, and opium. ${ }^{1}$ These analgesics were used for surgical analgesia as long as $2500 \mathrm{yr}$ ago. For example, in the ancient Indian work the Sushruta Samhita, written perhaps as early as $400 \mathrm{BC}$, it was advised that alcohol be used before surgery to produce insensibility to pain. ${ }^{2}$ Dioscorides (Circa 54-58 AD), a Greek physician and surgeon, recommended patients should take mandrake mixed with wine before limb amputation: "For such as cannot sleep, or are grievously pained, and upon whom being cut, or cauterized they wish to make a not-feeling pain". ${ }^{3}$ Celsus (AD 14-37) in $D e$ Medicina suggests the use of opium before surgery. ${ }^{4}$ In the Middle Ages, Theodoric, a 13th century monk and physician, described the spongia somnifera, a mixture of several narcotic substances including, opium, mandrake, henbane, mulberry, lettuce and hemlock, all boiled within a sponge, which was then sniffed to provide anesthesia for surgery. ${ }^{5}$

Despite the widespread use of these compounds for surgery there were no concomitant descriptions of their application for pain relief after surgery, although it seems logical they would have been so employed. Only opium and related compounds are still used as analgesics. The evolution of opium and its derivative morphine for postoperative pain relief will be reviewed.

\section{Opium}

Opium has been known for millennia to relieve pain and its use for surgical analgesia has been recorded for several centuries as noted above. However, its use as an agent for postoperative pain relief has only been described since the late 18th century, although it may have previously been used for this purpose but not recorded. Over the past two centuries, opium and its derivatives have emerged as the most effective analgesics for postoperative pain relief.

\section{Oral administration}

Laudanum, or tincture of opium, was a mixture of opium, alcohol, and various other ingredients. It was often given in whiskey or rum and became a widely used agent to prepare patients for surgery until the discovery of effective anesthesia. There were many recipes for laudanum, the most famous being that of Thomas Sydenham (1624-89). Sydenham's recipe, given in his work on dysentery in 1669, contained 1 pound sherry wine, 2 ounces opium, 1 ounce saffron,
1 ounce powder of cinnamon, and 1 ounce powder of cloves. ${ }^{6}$ Sydenham's laudanum was used in Europe and North America into the early 20th century. Several other opioid preparations were popular in the 18th and 19th centuries. "Black-drop", otherwise known as Lancaster or Quaker's Black Drop, contained opium, verjuice, nutmeg, saffron and yeast, and was reputedly three times stronger than laudanum. Paregoric was a weaker preparation, named after the Greek word for "soothing" or "consoling" and included opium, honey, licorice root, camphor, aniseed and wine. Dover's powder, first developed by the English physician and buccaneer Thomas Dover (1660-1742), contained opium, salt peter, tartar, licorice and ipecacuanha. ${ }^{7}$ Dover claimed, "In two or three hours at furthest the patient will be free from pain". In addition to producing his opium-containing "sweating powder", Thomas Dover was the second captain aboard the privateer Duke that rescued Alexander Selkirk (Robinson Crusoe) from one of the Juan Fernández islands in 1709.

The first record of postoperative analgesia was the use of opium in 1784 by the Glasgow-born London surgeon James Moore (1763-1834). He clearly realized the limitations of opium for surgical anesthesia, but praised its postoperative benefits when he wrote: "Opium...is highly expedient to abate the smarting of the wound after the operation is over, and to induce sleep; but the strongest dose we dare venture to give has little or no effect in mitigating the suffering of the patient during the operation". 8 In the same year, Moore also devised an appliance for compression of nerves producing numbness in a limb before surgery, presumably by neuropraxia. ${ }^{8}$

Five years later, the Scottish surgeon, Benjamin Bell (1749-1806) also found opium compounds to be good postoperative analgesics: "In general they prove most useful when given immediately after, when they very commonly alleviate that pungent soreness of which patients at this time usually complain; and by continuing to give them in adequate doses from time to time, we are often enabled to keep the patient easy and comfortable.... 9

Analgesia following laparotomy was first described by Ephraim McDowell (1771-1830) in May of 1816. McDowell gave "...a wine glass full of cherry bounce, and thirty drops of laudanum..." to a woman follow ing laparotomy and surgical removal of a six pound ovarian tumour, following which she recovered uneventfully. ${ }^{10}$ Of the five cases of laparotomy and ovariotomy in his two reports, this was the only one in which McDowell recorded using postoperative analgesia. ${ }^{10,11}$ 


\section{Rectal administration}

The first reference to postoperative opium using the rectal route of administration was by Shoemaker in 1891. In his Materia Medica and Therapentics he recommended a rectal opium suppository which “...quiets the nervous system after operations upon the female pelvis...". 12

\section{Morphine}

The isolation of morphine from crude opium was one of the most important discoveries of nineteenth century medicine. In the early 1800s Friedrich Serturner (1783-1841), a pharmacist's apprentice in Germany, was working on isolating the active principle of opium. Serturner's first discovery in 1805 , was a new acid, "mekonsaure" or "mohnsaure", present in opium. ${ }^{13}$ However, trials on dogs revealed that mekonsaure was inactive. He then reported finding a water-insoluble crystalline substance which had an "almost alkaline-like character"; he called this the "principium somniferum". ${ }^{14}$ Animal experiments proved this was indeed an active principle of opium. Serturner later named the active ingredient of opium "morphium" after the Greek god of dreams. ${ }^{15}$ In 1817 Serturner published another paper which, unlike his previous publications, received widespread attention. ${ }^{16}$ In a French translation of Serturner's work, Gay-Lussac added an editorial in which he suggested the name morphine rather than morphium. ${ }^{17}$

From the time of its discovery by Serturner, morphine was manufactured and used in an oral form, morphine acetate, which was a difficult and expensive salt to prepare. In 1831, William Gregory, an Edinburgh physician and chemist, discovered a cheap method of isolating and purifying morphine salts. ${ }^{18}$ However, there was no financial or clinical advantage in the use of morphine over paregoric and laudanum. These traditional media for delivering opium alkaloids orally were of similar cost and efficacy, and already established in the medical and public eye. It was not until the development of the hypodermic needle and syringe in the 1850s that the use of morphine became widespread.

\section{Parenteral administration}

Intravenous injection preceded subcutaneous administration by almost two centuries. Sir Christopher Wren (1632-1723), the English architect who designed St. Paul's Cathedral, was the first to inject liquid into a vein. Working with the celebrated chemist Robert Boyle in 1659, Wren injected an infusion of opium into a vein on the hind leg of a dog using a goose quill as the needle and an animal bladder as the syringe. He noticed that "the opium...did within a short time stupify, though not kill the dog". ${ }^{9}$

The first subcutaneous placement of morphine was described in 1836 by the French physician GV Lafargue. His "inoculation" method involved introducing a morphine paste under the epidermis by means of a vaccination lancet. ${ }^{20}$ Lafargue intended his inoculation method to have local effect but he speculated that systemic effect might be possible. To satisfy his curiosity he inoculated himself 13 times in the forearm and soon became overwhelmed by a sensation of extreme somnolence. ${ }^{2}{ }^{1}$ Unfortunately Lafargue was so preoccupied with his intention to create a local effect that he failed to recognize the significance of the systemic action of morphine even though he experienced it himself.

In 1845, the Irish surgeon Francis Rynd (18011861) became the first to introduce a fluid subcutaneously. In order to treat a patient with trigeminal neuralgia, Rynd developed a special instrument which could inject a morphine solution beneath the skin: "On the 3rd of June a solution of fifteen grains of acetate of morphia, dissolved in one drachm of creosote, was introduced to the supra-orbital nerve, and along the course of the temporal, malar, and buccal nerves, by four punctures of an instrument made for the purpose." 22 No description of the instrument was given - the predecessor of the modern hypodermic syringe - until his 1861 publication which described it as a retractable trocar and cannula that allowed fluid to enter the tissues by gravity alone. ${ }^{23}$

In 1853, the subcutaneous route of drug administration using a syringe and hollow needle was introduced by Alexander Wood of Edinburgh (1817-1884). Wood did not invent the syringe and hollow needle but modified a design already manufactured by a local chemist - a "Mr. Ferguson of Giltspur Street, London". ${ }^{24}$ Wood's intention was to produce a local effect by injecting morphine directly into the painful area. However, when he checked on his first patient the morning following a subcutaneous morphine injection he was "a little annoyed to find she had never wakened; the breathing also was somewhat deep, and she was roused with difficulty". ${ }^{2}$ Obviously Wood noticed the systemic effects of the morphine injection on his patient, but he maintained that its local analgesic effects were of primary importance.

The systemic action of a subcutaneous opioid injection was first fully understood in 1858 by the London surgeon, Charles Hunter. He published one paper on October 16, 1858 in the Medical Times Gazette advocating Wood's technique of morphine injection. ${ }^{25}$ Two weeks later he published another paper in the 
same journal, reporting that the injection of morphine at a site remote from the painful area produced equal pain relief. Hunter concluded "The idea that the relief results from localisation of the remedy in the painful part is erroneous-equal relief being afforded in either case". ${ }^{26}$ This was the beginning of a heated debate between Hunter and Wood, which was carried out through correspondence in the British Medical Journal and Lancet. Wood claimed the local effects of morphine injected subcutaneously were of primary importance, whereas Hunter claimed the systemic effects were paramount. Part of their debate also included an argument over the name for the technique. Hunter coined the term "hypodermical" in 1863, but Wood insisted that Hunter's "hypodermical" was identical to his own "subcutaneous" injection. ${ }^{27,28}$ Although both words refer to the same technique, the difference apparently lay in the purpose of the injection - local vs systemic. In the end, the Medical and Chirurgical Society of London appointed a special committee to settle the question of whether systemic or local effects of morphine injection were of primary importance. After two years the results were published and unanimously favoured Hunter. ${ }^{29}$ To some extent Wood has been vindicated by the discovery of peripheral opioid receptors. ${ }^{30,31}$

The first recorded use of subcutaneous morphine for postoperative pain-relief was in 1863 by James Paget (1814-1899). Paget gave $1 / 3$ grain $(20 \mathrm{mg})$ morphine by subcutaneous injection after a leg amputation under chloroform anesthesia, "...with the view of inducing freedom from pain, and some refreshing sleep after a return to consciousness." ${ }^{2} 2$ According to the report, this practice "... had been in use for some time at the Middlesex Hospital, and has afforded much comfort and ease, especially after many of the more important and painful operations". Paget recommended $1 / 4$ to $1 / 2$ grain $(15-30 \mathrm{mg})$, “....according to circumstances." 32

Although intravenous, subcutaneous and intramuscular routes of administration remain important methods of postoperative pain relief, great advances have been made with the introduction of regional techniques such as spinal and epidural injection.

\section{Neuraxial administration}

The New York neurologist, Leonard Corning (18551923) described the first use of spinal anesthesia in $1885 .{ }^{33} \mathrm{He}$ injected a cocaine solution into the space between the eleventh and twelfth thoracic vertebre in a man with "spinal weakness and seminal incontinence" and achieved decreased sensation and impaired reflexes in the lower extremities. ${ }^{3}$ It has been argued that
Corning unintentionally produced epidural rather than spinal anesthesia since no cerebrospinal fluid was reported to have been recovered in his syringes. ${ }^{34}$ Corning speculated his method might be used as an alternative to general anesthesia. His idea came to fruition $14 \mathrm{yr}$ later in the hands of the German surgeon August Bier (1861-1949) who described six cases in which "cocainization of the spinal cord" was performed for surgery on the lower extremities. ${ }^{35}$ All of his patients experienced post-anesthetic headache, nausea and vomiting. In the time-honored manner of the day, Bier and his assistant also attempted spinal injections of cocaine on each other, as recorded in this paper. They both developed severe headaches, and a number of cuts, bruises and burns were acquired while testing the efficacy of analgesia. ${ }^{35}$

One year later, Rudolph Matas (1860-1957), a vascular surgeon from New Orleans, was probably the first to inject an opioid by the spinal route. Matas often used a saline solution, containing both cocaine and morphine, for his spinal injections. The addition of morphine was intended to prolong the effect of cocaine as well as to provide sedation. ${ }^{36}$ Another early record of spinal injection of morphine comes from the annual report of the Dundee Royal Infirmary for 1909-10. In a list of 35 spinal anesthetics given that year, nine contained morphine combined with hyoscine and atropine. Although not specified in the report, the injections were probably given for pain relief and this may be the first deliberate use of spinal morphine for postoperative analgesia. ${ }^{37}$

Spinal opioid injections seemed to fall out of favour after these few anecdotal reports in the early 1900s. However, interest resumed after the biochemical demonstration, in 1973, of opioid receptors in the brain $^{38,39}$ and then in 1977 in the spinal cord. ${ }^{40,41}$ In 1976 , before the discovery of spinal cord opioid receptors, Yaksh and Rudy administered various opioids including morphine into the spinal subarachnoid space in rats. ${ }^{42}$ They noted that the opioids produced an action (blocked spinal reflexes and decreased response to painful stimuli) limited to the spinal cord and speculated these opioids caused a direct action on pain transmission in the substantia gelatinosa. ${ }^{42}$ The following year Snyder discovered that opioids exert their action through selective opioid receptors located in both the brain (especially in the limbic system and periaqueductal gray area of the brainstem) and spinal cord (particularly localized in the substantia gelatinosa), thus implying that opioid analgesia can be mediated in both regions. ${ }^{40,41}$

This demonstration of opioid receptors in the spinal cord led to the reintroduction of spinal opioid injection 
for clinical use. The next recorded use of spinal opioid injection in humans appears in the literature in 1978 when Wang used spinal morphine injections for relief of cancer pain. He also speculated that the technique might be useful for postoperative analgesia. ${ }^{4}$

A similar reintroduction of the use of epidural morphine occurred following the discovery of the opioid receptors in the spinal cord. In 1901, a new method of regional anesthesia was described in France by Jean Sicard (1872-1929) $)^{44}$ and one week later in the same journal by Fernard Cathelin (1873-1945). ${ }^{45}$ Both investigators described injection into the epidural fat surrounding the spinal cord dura. Sicard named the technique "extradural injection by the sacrococcygeal route" whereas Cathelin named the method "epidural injection by the sacral canal". Cathelin was the first to use the technique for surgery in four patients undergoing inguinal hernia repair. Unfortunately, a reduced but not complete loss of sensation was achieved in these operations. He also speculated that epidural injection might be a useful technique for pain relief in: rectal cancer, hemorrhoidal fissures and, an obstetrical indication, "accouchement douloureux". Almost $80 \mathrm{yr}$ were to pass before opioids were injected into the epidural space for pain relief by Behar and colleagues in 1979.46 Following this report, the use of epidural opioids for postoperative pain relief quickly gained acceptance and several publications in the early 1980s confirmed its efficacy. ${ }^{47-49}$ Ultimately, it was the discovery of opioid receptors in the spinal cord that led to the effective treatment of postoperative pain by neuraxial administration without profound sedative effects.

\section{Submucosal administration}

Submucosal routes of administration have also been used with success in the delivery of opioids postoperatively. These include transnasal, transmucosal, and sublingual administration. For example, transnasal and transmucosal opioids have been used for pre-induction of anesthesia in children ${ }^{50,51}$ and have the potential for postoperative use. Sublingual buprenorphine has been used postoperatively with good analgesic success on both a scheduled and patient-demand basis. ${ }^{5}$

\section{Transdermal administration}

The transdermal delivery of opioids has also gained recent popularity for both palliative care and postoperative pain control. In particular, the transdermal fentanyl patch has been used since the late 1980s for postoperative analgesia. ${ }^{5}$

\section{Intra-articular administration}

Recently, opioids have been found to exert analgesic effects by acting at peripheral sites, particularly where there is inflammation. In 1991, Stein and colleagues were the first to describe that morphine injected intraarticularly in the knee joint following arthroscopy considerably reduced postoperative pain. ${ }^{30}$ The analgesic effect of the morphine was shown to be mediated by a local action and not by CNS redistribution. Since this study, numerous randomized controlled trials have been done to assess reduction of postoperative pain following injection of opioid into the knee. A systematic review of 36 of these randomized controlled trials concluded that intra-articular morphine may be effective in reducing postoperative pain following knee surgery. ${ }^{54}$

Other opioid delivery systems currently under investigation and with the potential for postoperative pain control include the pulmonary route of administration using a powder form of morphine or fentanyl.

\section{Patient controlled analgesia}

One currently popular method of pain control, patient controlled analgesia (PCA), was first proposed by the Boston dentist William Morton (1819-1868) for use in labour. ${ }^{5}$ Morton first suggested "self-serve" anesthesia in 1847 by allowing the woman in labour to hold an ether sponge to her face when she felt pain. He wrote: “...it is best, in most cases in this stage of labour, to allow her to hold the sponge herself, and apply it to her mouth when she feels a pain coming on." This was the forerunner of patient-controlled inhalation analgesia with nitrous oxide and oxygen mixtures, popular in the 1940s-70s.

The first use of intravenous opioids with patient controlled analgesia was also in obstetrics. In a 1969 lecture, James S. Scott, from the University of Leeds in England, reported the use of "self-service" intravenous analgesic administration in his obstetric practice over the preceding five years. ${ }^{56}$ This was offered to any woman who had experienced inadequate analgesia in her first labour. She could be given control of her own pain relief through a specially designed apparatus with a spring, which the woman compressed when she needed pain relief, allowing meperidine to be delivered through the intravenous infusion. The first postoperative use of PCA with an opioid was described by Sechzer in 1967. ${ }^{57}$ Postoperative patients pressed an analgesicdemand button which alerted the nurse to give a small amount of intravenous morphine or meperidine until the pain was controlled. Sechzer concluded that this "analgesic-demand method was ....an excellent system for treatment for postoperative pain". ${ }^{57}$

Since intravenous PCA was introduced by Scott, new delivery systems have been developed using the 
same concept of patient control over dosing. Patientcontrolled epidural analgesia (PCEA) with either an opioid or a combination of opioid and local anesthetic is used both in obstetrics, and for postoperative analgesia. ${ }^{58-60}$ Preferred opioids for PCEA include synthetic compounds such as fentanyl, sufentanil, and alfentanil because, as opposed to morphine, they have high lipophilicity and thus a rapid onset of action. Subcutaneous PCA using morphine has also been reported in the literature as an effective method for postoperative pain control. ${ }^{61}$ Patient-controlled intranasal analgesia (PCINA) using meperidine or fentanyl, but not morphine, is a recent development which has been used in palliative care ${ }^{62}$ as well as for postoperative pain management. ${ }^{62,63}$

Conclusion

Nearly $5000 \mathrm{yr}$ after opium was first cultivated and isolated by the Sumerians, opium and its derivatives remain the best analgesics. Since the isolation of morphine from opium almost $200 \mathrm{yr}$ ago many different delivery systems have been used for its administration. Basic research demonstrated the existence of opioid receptors in 1973, opening new avenues for the use of morphine in pain relief. Although many new painrelieving compounds have been developed in the twentieth century, morphine remains the standard by which all new analgesic preparations are judged. For those who practise surgery and are responsible for postoperative pain relief the sentiments of Thomas Sydenham, extolling the virtues of opium more than three centuries ago, remain relevant: "None of us would be calloused enough to practise our profession without it".

Acknowledgment

The authors wish to acknowledge the assistance of Dr. Orlando Hung.

\section{References}

1 Tallmadge GK. Some anesthetics of antiquity. J Hist Med Allied Sci 1946; 1: 515-20.

2 Dwarakanath SC. Use of opium and cannabis in traditional systems of medicine in India. Bull Narc 1965; 17: 15-9.

3 Gunther RT. The Greek Herbal of Dioscorides, Book IV. London: Hafner Publishing Company, 1968: 473.

4 Kirkup J. Surgery before general anesthesia. In: Mann RD (Ed.). The History of the Management of Pain. Casterton Hall: Parthenon Publishing Group, 1988: $15-30$.

5 Bergman NA. The Genesis of Surgical Anesthesia. Park Ridge: Wood Library-Museum of Anesthesiology, 1998: 18.
6 Sigerist HE. Laudanum in the works of Paracelsus. Bull Hist Med 1941; 9: 530-44.

7 Macht DI. The history of opium and some of its preparations and alkaloids. JAMA 1915; 64: 477-81.

8 Moore J. A method of preventing or diminishing pain in several operations. London: J Cadell, 1784. Cited by Bergman NA. The Genesis of Surgical Anesthesia. Park Ridge: Wood Library-Museum of Anesthesiology, 1998: 349.

9 Bell B. A System of Surgery, 6th ed., Vol. 2. Edinburgh: Bell and Bradfute, 1796: 393-7.

10 McDowell E. Three cases of extirpation of diseased ovaria. Eclect Rep Analyt Rev (Philadelphia) 1817; 7: 242-4.

11 McDowell E. Observations on diseased ovaria. Eclect Rep Analyt Rev (Philadelphia) 1819; 9: 546-53.

12 Shoemaker JV. Materia Medica and Therapeutics, Vol 2. Philadelphia, 1891: 785 .

13 Serturner FW. Trommsdorff's Journal der Pharmazie fur Aerzte, Apotheker und Chemisten 1805; 13: 229-35.

14 Serturner FW. Trommsdorff's Journal der Pharmazie fur Aerzte, Apotheker und Chemisten 1806; 14: 47-93.

15 Lockemann J. On Serturner. J Chem Educ 1951; 28: 277.

16 Serturner $F W$. Ueber das Morphium, eine neue salzfahige Grundlage, und die Mekonsaure, als Hauptbestandtheile des Opiums. Gilbert's Annalen der Physik 1817; 55: 56-89.

17 Serturner $F W$. De la morphine et de l'acide meconique, consideres comme parties essentielles de l'opium. Annales de Chimie et de Physique 1817; 5: 21-42.

18 Gregory $W$. On a process of preparing economically the muriate of morphia. Edin Med Surg J 1831; 35: 331-8.

19 Wren $C$ An account of the rise and attempts, of a way to conveigh liquors immediately into the mass of blood. Phil Trans 1665; 1: 128-30.

20 Lafargue $G V$. Note sur les effets de quelques medicaments introduits sous l'epiderme. Acad Sci Paris 1836; 2: 397-8, 434 .

21 Lafargue GV. Lettre de M. le docteur Lafargue de Saint-Emilion, sur l'inoculation de la morphine avec la lancette. Bull Acad Med Paris 1836; 1: 13-18, 40-2.

22 Rynd F. Neuralgia- introduction of fluid to the nerve. Dublin Med Press 1845; 13: 167-8.

23 Rynd F. Description of an instrument for the subcutaneous introduction of fluids in affections of the nerves. Dublin Quarterly Journal Med Sci 1861; 32: 13.

$24 \operatorname{Wood} A$. New method of treating neuralgia by the direct application of opiates to the painful points. Edin Med Surg J 1855; 82: 265-81. 
25 Hunter C. On narcotic injections in neuralgia. Med Times Gazette 1858; 2: 408-9.

26 Hunter C. On narcotic injections in neuralgia. Med Times Gazette 1858; 2: 457-8.

27 Wood $A$. Treatment of neuralgic pains by narcotic injections. BMJ 1858; 1: 721-3, 755.

28 Hunter $C$. Practical remarks on the hypodermical treatment of disease. Lancet 1863; 2: 444-5, 675-6.

29 Howard-Jones $\mathrm{N}$. A critical study of the origins and early development of hypodermic medication. J Hist Med 1947; 2: 201-49.

30 Stein C, Comisel K, Haimerl E, et al. Analgesic effect of intraarticular morphine after arthroscopic knee surgery. N Engl J Med 1991; 325: 1123-6.

31 Stein C, Schäfer M, Hassan AHS. Peripheral opioid receptors. Ann Med 1995; 27: 219-21.

32 Paget J. Subcutaneous injection of morphia after operation, before restoration of consciousness after chloroform. Lancet 1863; 1: 48.

33 Corning JL. Spinal anaesthesia and local medication of the cord. NY Med J 1885; 42: 483-5.

34 Vandam LD. On the origins of intrathecal anesthesia. Reg Anesth Pain Med 1998; 23: 335-9.

35 Bier $A$. Experiments regarding the cocainization of the spinal cord. Reprinted in "Classical File" Surv Anesthesiol 1962; 6: 352-8. (originally from Dtsch Z Chir 1899; 51: 361-9.)

36 Matas $R$. Local and regional anesthesia with cocain and other analgesic drugs, including the subarachanoid method, as applied in general surgical practice. Philadelphia Med J 1900; 6: 820-43.

37 McGowan SW. Highlights of anaesthesia in Dundee. In: Barr M, Boulton TB, Wilkinson DJ (Eds.). Essays on the History of Anaesthesia. London: Royal Society of Medicine Press, 1996: 71-3.

38 Pert CB, Snyder SH. Opiate receptor: demonstration in nervous tissue. Science 1973; 179: 1011-4.

39 Kuhar MJ, Pert CB, Snyder SH. Regional distribution of opiate receptor binding in monkey and human brain. Nature 1973; 245: 447-50.

40 Snyder SH. Opiate receptors in the brain. N Engl J Med 1977; 296: 266-71.

41 Snyder SH. Opiate receptors and internal opiates. Sci Am 1977; 236: 44-56.

42 Yaksh TL, Rudy TA. Analgesia mediated by a direct spinal action of narcotics. Science 1976; 192: 1357-8.

43 Wang $\Upsilon K$. Soulagement de la douleur par injection intrathécale de sérotonine ou de morphine. Annals Anesth Fr 1978; 19: 371-2.

44 Sicard JA. Les injections medicamenteuses extradurales par voie sacro-coccygienne. Compte Rend Soc de Biol 1901; 53: 396-8.

45 Cathelin F. Une nouvelle voie d'injection rachidienne.
Méthode des injections epidurales par le procédé du canal sacré. Applications a l'homme. Compte Rend Soc de Biol 1901; 53: 452-3.

46 Behar M, Magora F, Olshwang D, Davidson JT. Epidural morphine in treatment of pain. Lancet 1979; 1: 527-30.

47 Bromage PR, Camporesi E, Chestnut D. Epidural narcotics for postoperative analgesia. Anesth Analg 1980; 59: 473-80.

48 Reiz S, Ablin J, Abrenfeldt B, Andersson M, Andersson $S$. Epidural morphine for postoperative pain relief. Acta Anaesthesiol Scand 1981; 25: 111-4.

49 Rawal N, Sjörstrand U, Dablström B. Postoperative pain relief by epidural morphine. Anesth Analg 1981; 60: 726-31.

50 Henderson JM, Brodsky DA, Fisher DM, Brett CM, Hertzka RE. Pre-induction of anesthesia in pediatric patients with nasally administered sufentanil. Anesthesiol 1988; 68: 671-5.

51 Streisand JB, Hague B, van Vreeswijk H, et al. Oral transmucosal fentanyl premedication in children. Anesth Analg 1987; 66: S170.

52 Vincenti E. Sublingual opiates in acute pain. Adv Pain Res Ther 1990; 14: 227-31.

53 Gourlay GK, Kowalski SR, Plummer JL, Cherry DA, Gaukroger P, Cousins MJ. The transdermal administration of fentanyl in the treatment of postoperative pain: pharmacokinetics and pharmacodynamic effects. Pain 1989; 37: 193-202.

54 Kalso E, Tramèr MR, Carroll D, McQuay HJ, Moore

$R A$. Pain relief from intra-articular morphine after knee surgery: a qualitative systematic review. Pain 1997; 71: 127-34.

55 Raper HR. Man Against Pain. The Epic of Anesthesia. New York: Prentice-Hall, Inc., 1945; 212-3.

56 Scott JS. Obstetric analgesia. A consideration of labor pain and a patient-contolled technique for its relief with meperidine. Am J Obstet Gynecol 1970; 106: 959-78.

57 Sechzer $P H$. Objective measures of pain and pain relief following cardiovascular surgery. Rev Argent Angiol 1967; 1: 9-12.

58 Rawal N. Epidural and spinal agents for postoperative analgesia. Surg Clin North Am 1999; 79: 313-44.

59 Komatsu H, Matsumoto S, Mitsubata H, Abe K, Toriyabe $S$. Comparison of patient-controlled epidural analgesia with and without background infusion after gastrectomy. Anesth Analg 1998; 87: 907-10.

60 Lin SS, Allen HW, Olsson GL. Patient-controlled epidural analgesia with bupivacaine and fentanyl on hospital wards. Prospective experience with 1,030 surgical patients. Anesthesiology 1998; 88: 688-95.

61 Hopkins D, Shipton EA, Potgieter D, et al. Comparison of tramadol and morphine via subcutaneous PCA fol- 
lowing major orthopaedic surgery. Can J Anaesth 1998; 45: 435-42.

62 O'Neil G, Paech M, Wood F. Preliminary clinical use of a patient-controlled intranasal analgesia (PCINA) device. Anaesth Intensive Care 1997; 25: 408-12.

63 Striebel HW, Koenigs D, Krämer J. Postoperative pain management by intranasal demand-adapted fentanyl titration. Anesthesiology 1992; 77: 281-5. 